\title{
Late Pleistocene and Holocene Paleoearthquake Activity of the Olinghouse
}

\section{Fault Zone, Nevada}

\author{
by Richard W. Briggs and Steven G. Wesnousky
}

\begin{abstract}
Paleoseismic trenching and fault surface trace mapping indicate that the Olinghouse fault zone, a northeast trending, left-lateral strike-slip fault located in the northern Walker Lane, Nevada, has been the source of multiple latest Pleistocene and Holocene surface-rupturing earthquakes. A trench exposure near the eastern end of the fault records two, and possibly three, earthquakes after $3360 \pm 190 \mathrm{cal}$. yr B.P. and two trenches at the western end of the fault contain evidence for two earthquakes after 19,800 \pm 630 cal. yr B.P., with the most recent earthquake occurring after $1935 \pm 70 \mathrm{cal}$. yr B.P. The apparent higher frequency of recent earthquakes at the eastern end of the fault may reflect triggered slip on the Olinghouse fault zone due to earthquakes on the conjugate northwest-trending, right-lateral Pyramid Lake fault. Repeated late Pleistocene and Holocene earthquakes on the Olinghouse fault zone demonstrate that northwest-directed, right-lateral shear of the northern Walker Lane is accommodated in part by northeast-trending left-lateral faults.
\end{abstract}

\section{Introduction}

Geodetic data indicate that up to $25 \%$ of relative PacificNorth America plate motion occurs east of the Sierra Nevada (Minster and Jordan, 1987; Ward, 1990), with most of this deformation accommodated on faults of the western Basin and Range and the Walker Lane (Fig. 1) (Dokka and Travis, 1990; Savage et al., 1990; Thatcher et al., 1999; Bennett et al., 2003; Hammond and Thatcher, 2004). The Walker Lane is a zone of northwest-directed, right-lateral shear east of the Sierra Nevada and subparallel to the San Andreas fault zone (Fig. 1a) (Stewart, 1988; Pezzopane and Weldon, 1993). Recent Global Positioning System (GPS) geodetic measurements show that $6 \pm 2 \mathrm{~mm} / \mathrm{yr}$ of northwest-directed, rightlateral shear, or $10-15 \%$ of relative Pacific-North America plate motion, occurs across the northern Walker Lane (Fig. 1b) (Thatcher et al., 1999; Dixon et al., 2000; Svarc et al., 2002; Hammond and Thatcher, 2004). The Olinghouse fault zone is an active, northeast-trending left-lateral strike-slip fault located within the northern Walker Lane (Fig. 1) (Bonham, 1969; Sanders and Slemmons, 1979, 1996; Stewart, 1988; Yount et al., 1993; Robyn, 1994). Previous studies (Sanders and Slemmons, 1979, 1996) have suggested that the Olinghouse fault is among the most active faults in a complex assemblage of northeast-trending left-lateral strikeslip faults, north-trending normal faults, and northwesttrending right-lateral strike-slip faults that accommodate shear across the northern Walker Lane (Fig. 1b). Here we build on these previous studies and report mapping and paleoseismic trench observations bearing on the style of faulting and timing of paleoearthquakes on the Olinghouse fault.
We then use our observations to discuss the role of the Olinghouse fault in accommodating shear of the northern Walker Lane.

\section{Fault Location, Geometry, and General Neotectonic Features}

The active trace of the Olinghouse fault zone extends $25 \mathrm{~km}$ from near Tracy to Dodge Flat, where it intersects the right-lateral, northwest-trending Pyramid Lake fault zone (Fig. 2). The Olinghouse fault zone is gently arcuate and changes strike from $\sim \mathrm{N} 60^{\circ} \mathrm{E}$ near Tracy to $\sim \mathrm{N} 30^{\circ} \mathrm{E}$ at Dodge Flat (Fig. 2). Figure 3, a neotectonic strip map along the fault, shows three geologically distinct sections (eastern, central, and western) and highlights the geomorphic features that record Quaternary faulting in each section. These sections are briefly discussed in turn subsequently.

Along the eastern section of the Olinghouse fault and near its intersection with the Pyramid Lake fault, recent surface-rupturing earthquakes are preserved as scarps that offset post-Lahontan $(<15.5 \mathrm{ka}$; Adams and Wesnousky, 1999) alluvium (Fig. 3). Strike-slip motion along the eastern portion of the fault is recorded by left-lateral offset of a channel bank, left-lateral channel deflection at a shutter ridge, and en echelon fault scarps (Fig. 3). Progressively greater vertical offset of successively older surfaces (Fig. 4) reflects repeated earthquakes.

The central portion of the fault is characterized by a discontinuous zone of faulting that displaces Tertiary vol- 

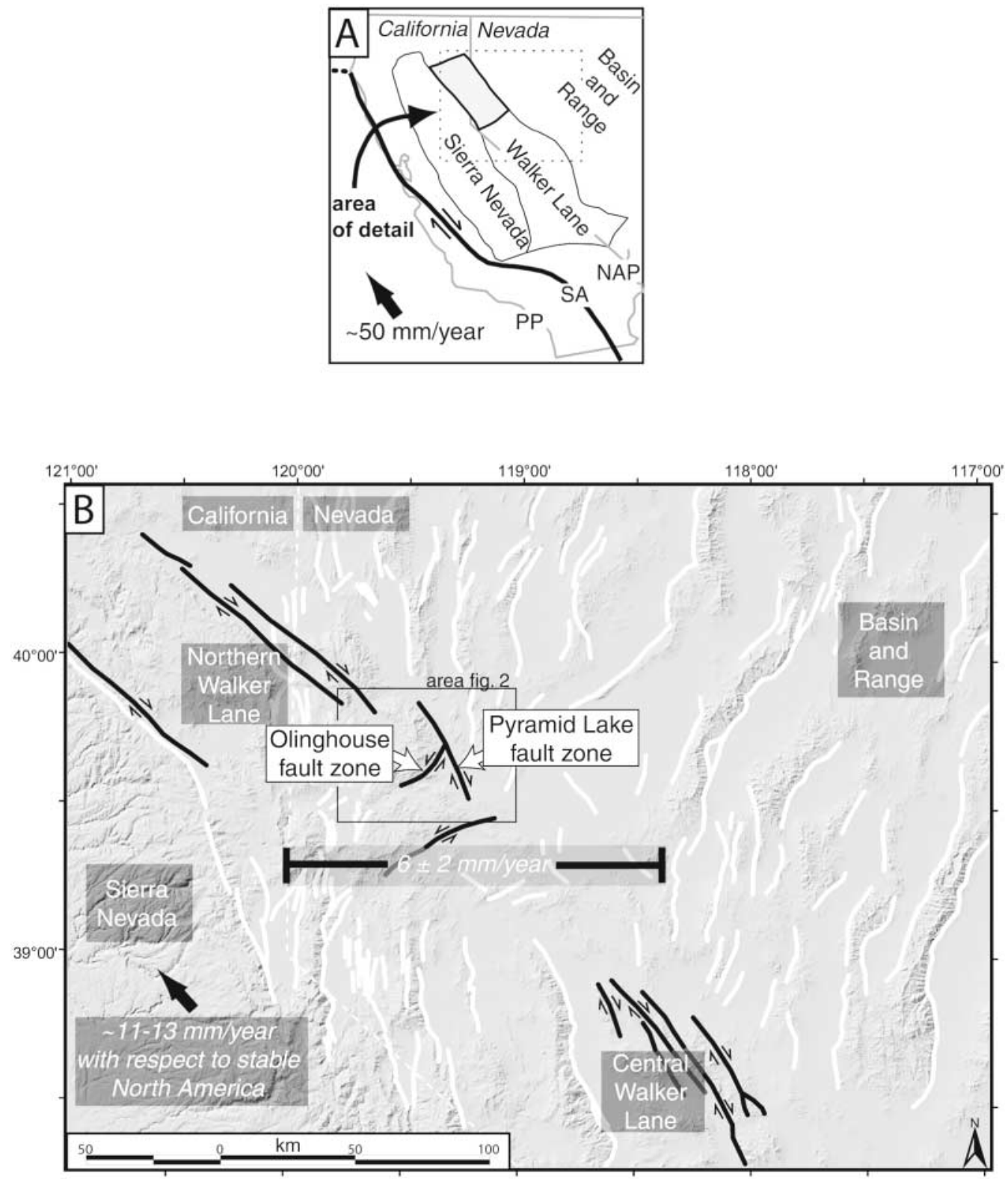

Figure 1. (A) Location of the northern Walker Lane (gray shading). PP, Pacific plate; SA, San Andreas fault zone; NAP, North America plate. Dashed box shows location of panel b. (B) Location of the Olinghouse fault zone with respect to active faults of the northern Walker Lane and the Basin and Range. Black faults are strike slip, white faults are normal (modified from U.S. Geological Survey, 2003, and Dohrenwend et al., 1996). GPS geodetic surveys show that $6 \pm 2 \mathrm{~mm} / \mathrm{yr}$ of northwestdirected right-lateral shear occurs across the northern Walker Lane (Thatcher et al., 1999; Hammond and Thatcher, 2004). Velocity of Sierra Nevada from Dixon et al. (2000).

canic bedrock of the Pah Rah Range (Bonham, 1969; Greene et al., 1991; Garside et al., 2000) and forms a broad trough in the range front (Fig. 3). Distributed fault traces in bedrock tend to cut across topography in the central section and scarps in young alluvium are uncommon. A large paleolandslide that may have been triggered by coseismic shaking is aligned along the fault in this section (Fig. 3).

The western section (Fig. 3) is marked by fairly contin- uous scarps in alluvium and prominent bedrock/colluvium fault contacts that form a series of grabens and rhombohedral depressions. Figure 5 shows a vertical, low-sun-angle airphoto and accompanying topographic map of an offset debris flow levee, offset channel thalwegs, and a small pushup in a contractional right step that record left-lateral slip along this section. The debris flow levee is composed of cobbles and boulders of vesicular basalt and is offset sharply 


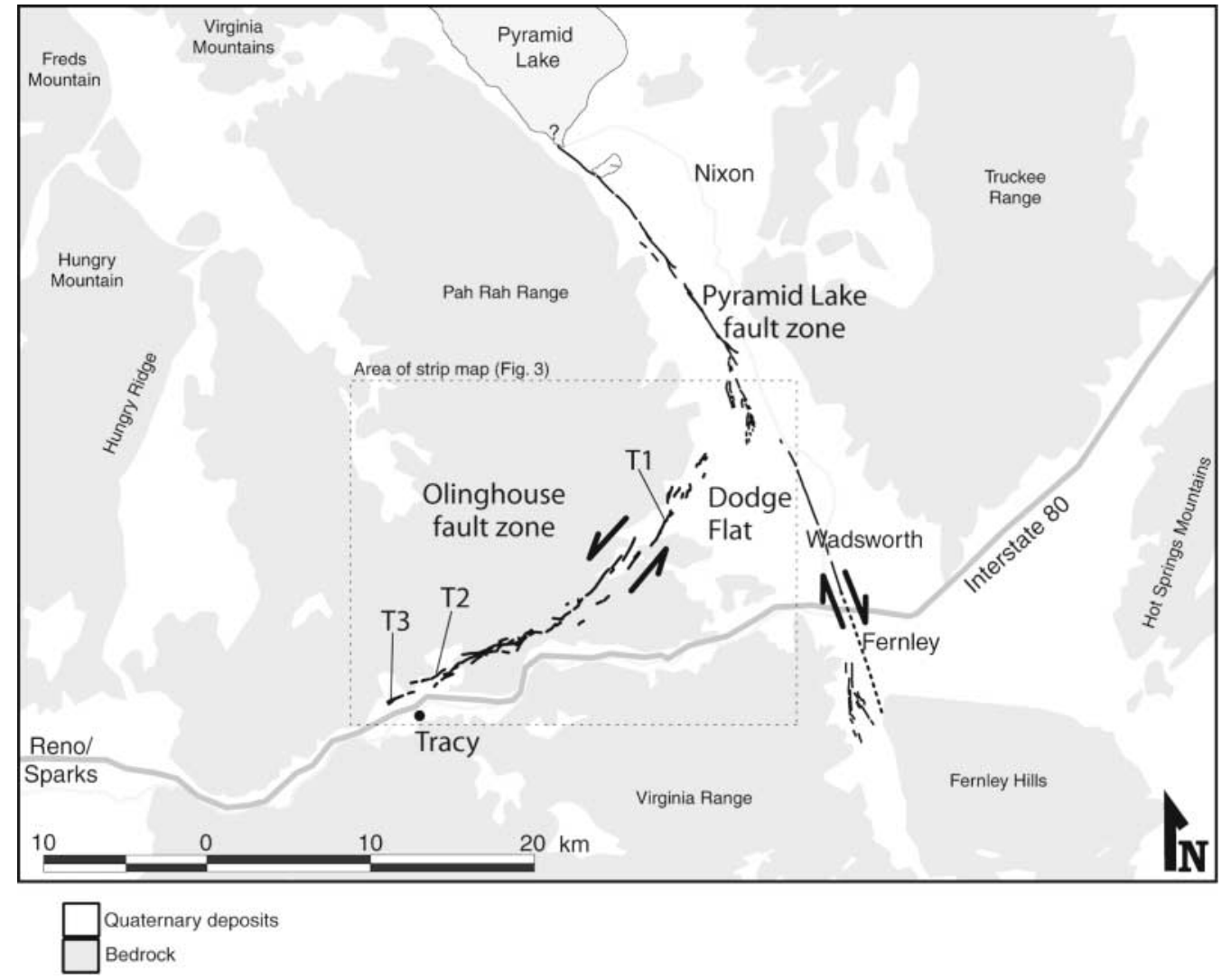

Figure 2. Location of the Olinghouse fault zone with respect to the conjugate Pyramid Lake fault zone. T1, trench 1; T2, trench 2; T3, trench 3. Location of Figure 3 shown by dashed box. Distribution of bedrock and alluvium modified from Stewart and Carlson (1978).

along an uphill-facing scarp (Fig. 5b). The well-defined crest and western edge of the debris flow levee are offset $3.0 \pm$ $0.6 \mathrm{~m}$ left-laterally and $0.5 \pm 0.1 \mathrm{~m}$ vertically. Two channel thalwegs adjacent to the offset debris flow levee (labeled 1 and 2 in Fig. 5b) also are offset left-laterally. The smaller of these offsets (channel 1; Fig. 5b) is $2.75 \pm 0.75 \mathrm{~m}$, and the similarity between this value and the $3.0 \pm 0.6 \mathrm{~m}$ offset of the debris flow levee suggests that the most recent coseismic displacement along this section of the fault was $\sim 2.75$ $3.0 \mathrm{~m}$. Channel 2 (Fig. 5b) is apparently offset $10 \pm 2 \mathrm{~m}$ left-laterally. If the apparent offset of channel 2 is due to fault displacement and not deflection along the uphill-facing scarp, then channel 2 records multiple left-lateral surface ruptures.

At the far western extent of the mapped active trace the fault forms discontinuous scarps in alluvium, with recent strike-slip motion preserved as uphill-facing scarps formed in Lahontan erosional surfaces and post-Lahontan alluvium $(<15.5 \mathrm{ka}$; Figs. 3 and 6). We did not observe fault scarps in young deposits along the projection of the mapped trace (Fig. 3) to the west, although we cannot rule out continuation of the active trace discontinuously in the bedrock (Bonham and Bell, 1993; Garside et al., 2000) or along a subparallel strand (Sanders and Slemmons, 1996).

\section{Paleoearthquake Observations}

\section{Trench 1}

We excavated trenches across the fault in three locations (Figs. 2 and 3) to investigate paleoearthquake recurrence of the Olinghouse fault. Trench 1 was emplaced across a welldefined, continuous, 0.6-m (vertical separation) east-facing scarp in young alluvium along the $\sim \mathrm{N} 35^{\circ} \mathrm{E}$ trending eastern section of the fault, $10 \mathrm{~km}$ west-northwest of Wadsworth (Fig. 4). Sediment exposed in trench 1 comprises two primary facies, a fluvial channel facies and a debris flow facies (Fig. 7). The occurrence of these deposits is consistent with the medial fan location of the trench. Distinctive units are recognized on the basis of bounding unconformities and relative abundance of debris flow or channel gravel sediments. Mapped units are continuous across and displaced by the fault; their relative offsets aid identification of discrete faulting events.

Clear stratigraphic and structural evidence for multiple earthquakes is exposed in trench 1 (Fig. 7). We interpret two events, a penultimate and most recent event. Scarp-derived colluvium and muddy channel fill (unit C1) deposited after the penultimate event caps sheared material within fault strand FE (Fig. 7). Units below colluvial unit C1 are offset 


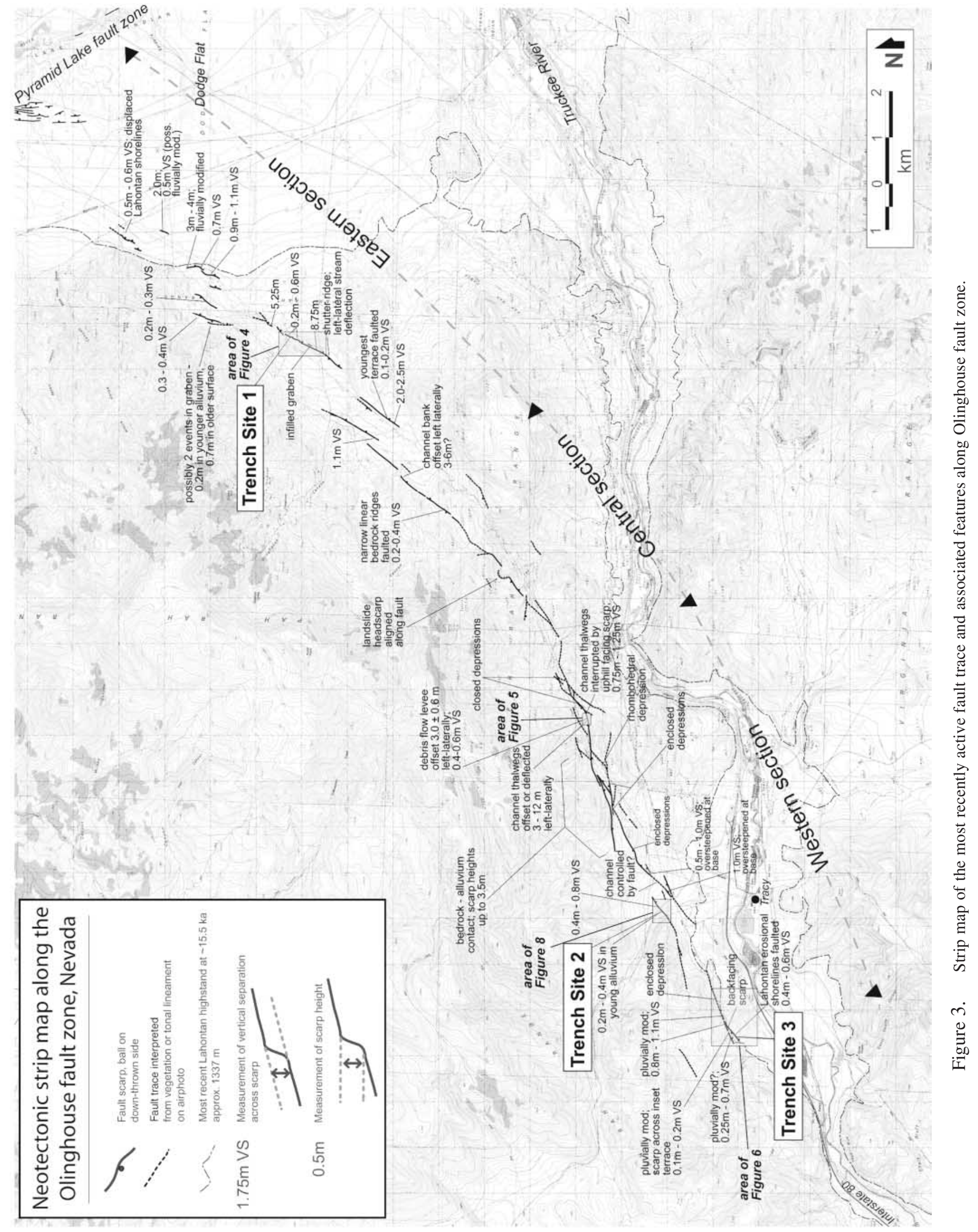



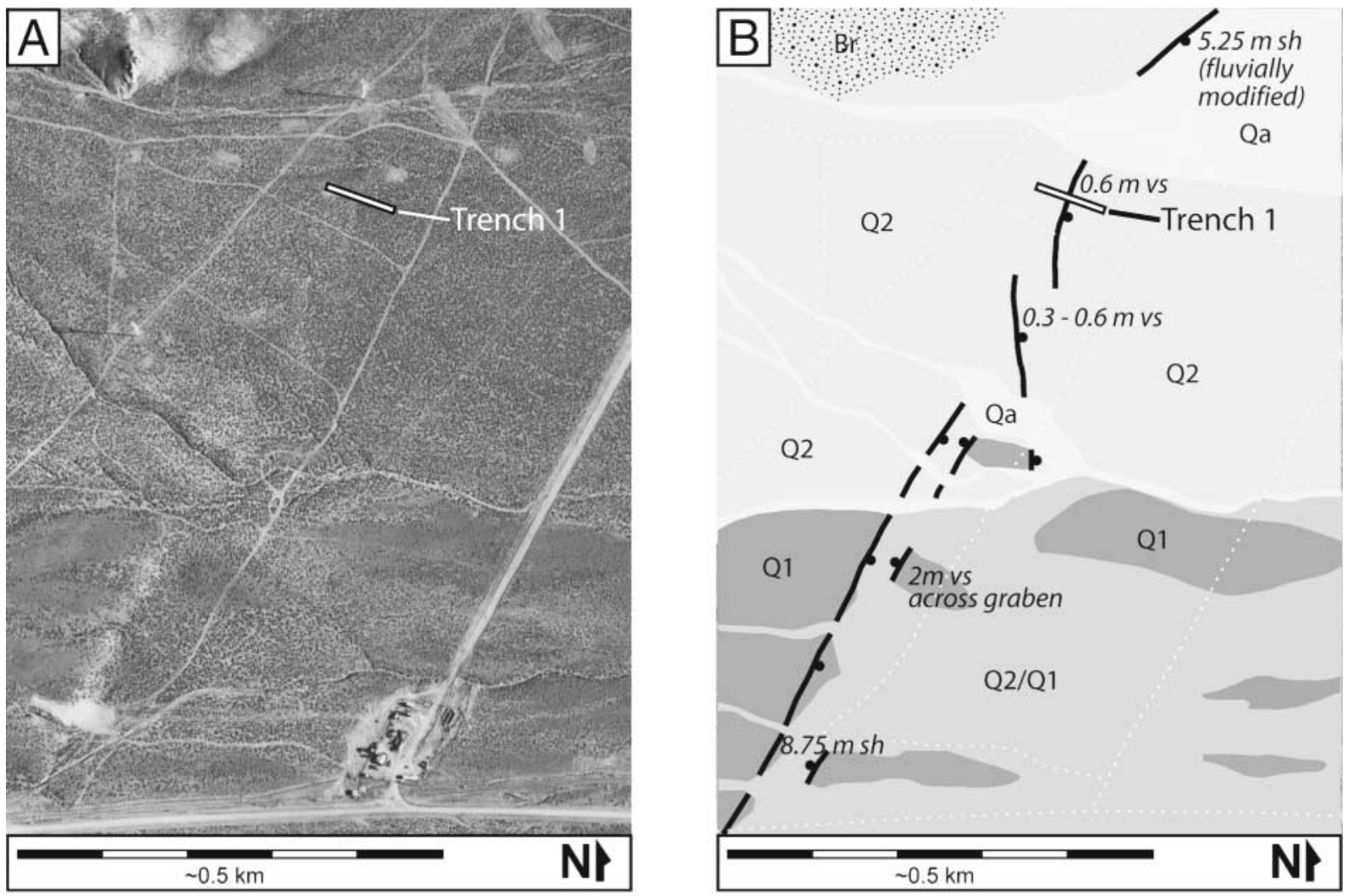

Figure 4. (A) Low-sun-angle vertical airphoto showing location of trench 1. See Fig. 3 for location. (B) Simplified surficial geologic map of airphoto area. Black lines are fault scarps with ball on down dropped side. Qa, active alluvium; Q2 through Q1, progressively older alluvium; Br, bedrock; sh, scarp height; vs, vertical separation; dotted white lines, selected roads.

vertically $70-90 \mathrm{~cm}$. After the penultimate event, units 4 and $\mathrm{C} 1$ were partially stripped, then overlain by unit 5 that was subsequently faulted in the most recent event. Unit 5 is offset vertically $30 \mathrm{~cm}, 40-60 \mathrm{~cm}$ less than those faulted by previous events. Apparent thrusting of some of the uppermost units and facies mismatches across the deeper portions of the fault indicate primarily strike-slip motion. Although vertical displacements are observed across both fault strands FW and FE (Fig. 7), significant facies changes occur only across fault strand FE, suggesting that partitioning of normal (on fault strand FW) and strike-slip motion (on fault strand FE) occurs between fault strands. Throughout the exposure, fault strands extend nearly to the surface where they are capped by a thin vesicular silt (Av soil horizon) cap. The total apparent normal component of displacement of mapped units in the trench $(70-90 \mathrm{~cm})$ is slightly larger than the vertical separation seen at the ground surface $(60 \mathrm{~cm})$, reflecting strike-slip displacement.

A third earthquake may be recorded by the apparent thickening of unit 4 across the eastern fault strand FE (Fig. 7). The change in thickness of unit 4 suggests deposition across a pre-existing fault scarp and implies displacement on fault strand FE that postdates unit 3 and predates unit 4 (Fig. 7). Although we recognize this possibility, sev- eral observations are inconsistent with this interpretation. First, the thickness changes of unit 4 across fault strand FE are probably due to erosion during emplacement of overlying unit 5, rather than deposition of unit 4 against a preexisting scarp. Second, the offset of the base of unit 4 (70 $\mathrm{cm}$ ) is somewhat smaller than the offsets of units 2 and 3 $(85-90 \mathrm{~cm})$, but because the fault is predominantly strike slip with coseismic lateral offsets that may be $\sim 3 \mathrm{~m}$ (Fig. 5 ) and bedding attitudes are not strictly horizontal, differential vertical offsets alone are not diagnostic of individual earthquakes. Finally, we do not observe scarp-derived colluvium associated with this hypothesized oldest event. Taken together, the observations suggest that a third earthquake preserved in trench 1 is possible but unlikely.

Age control for paleoearthquakes observed in trench 1 is provided by tephra correlation and radiocarbon dating of detrital charcoal (Fig 7; Table 1). The Mount Mazama tephra (7627 \pm 150 cal. yr B.P.; Zdanowicz et al., 1999) is present in clean pods and lightly reworked $<5$-cm layers in unit 2 along much of the length of the trench (Fig. 7), including within the fault zone. The maximum age of the faulted deposits of unit 3 is $3360 \pm 190$ cal. yr B.P., determined from accelerator mass spectrometry (AMS) ${ }^{14} \mathrm{C}$ dating of detrital charcoal (sample Oling C-1, Fig. $7 ;{ }^{14} \mathrm{C}$ calibrations from 


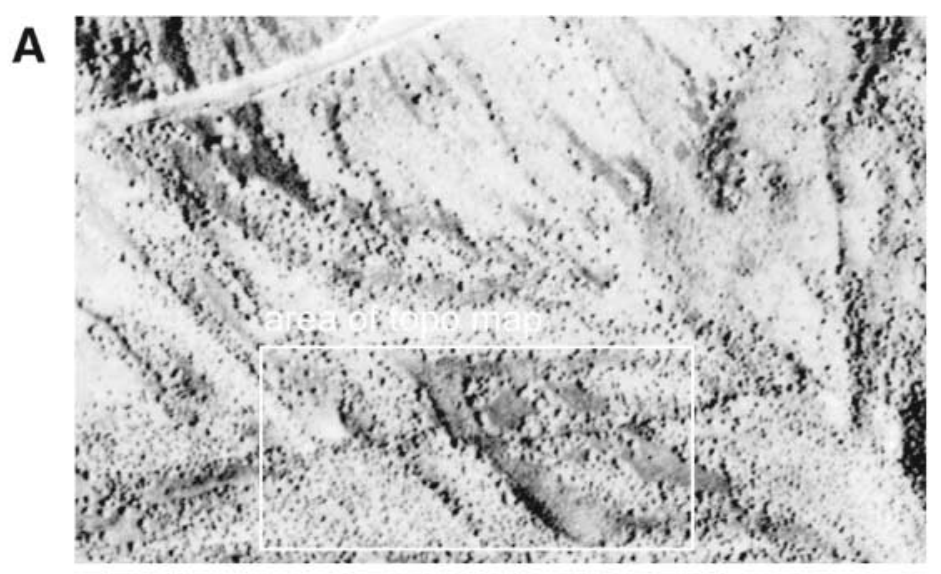

B

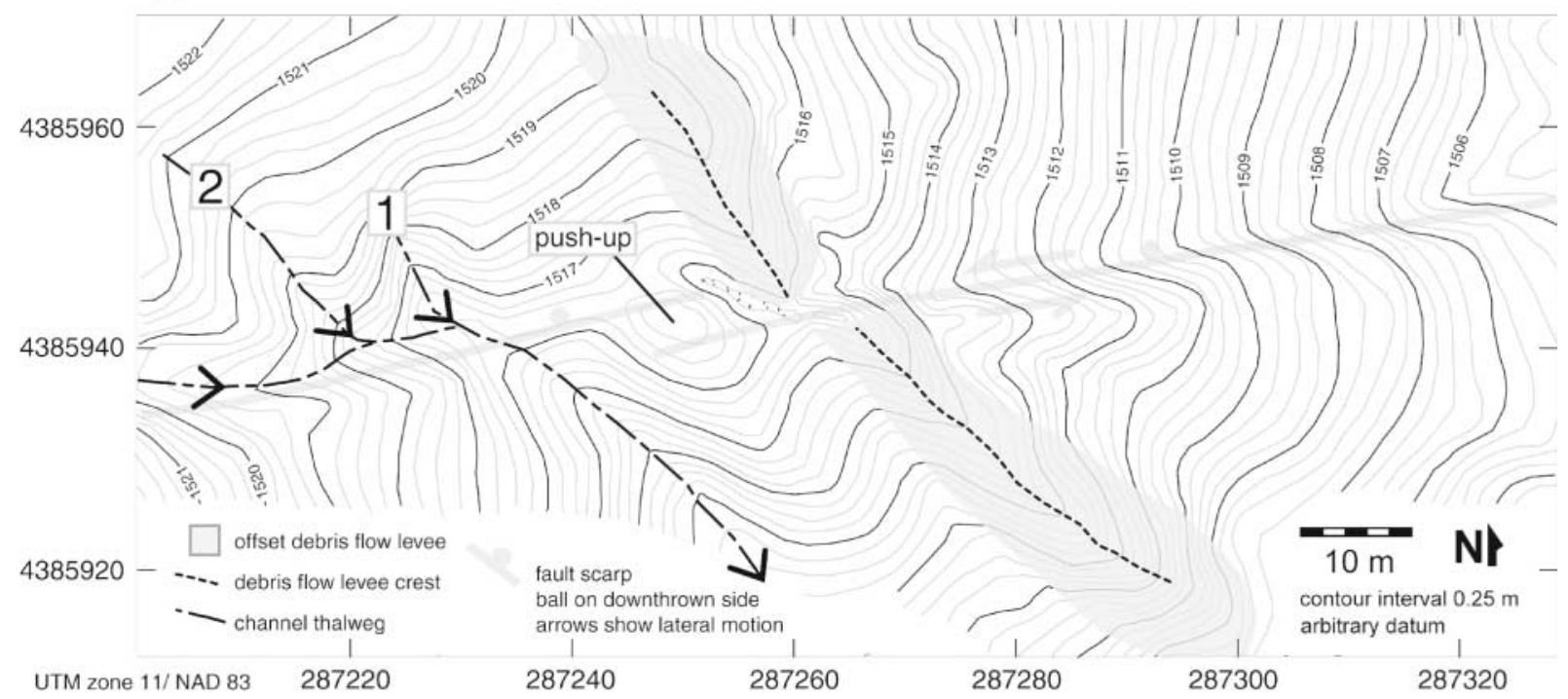

Figure 5. (A) Low-sun-angle vertical airphoto showing fault trace (between white arrows) and geomorphic features offset left laterally. See Figure 3 for location. (B) Topographic map of left-laterally offset debris flow levee (shaded area) and channel thalwegs (dashed lines).

Stuiver and Reimer [1993]) obtained from the muddy, nonbioturbated matrix of a debris flow layer. Thus, the exposure records two, and possibly three events since $3360 \pm 190$ cal. yr B.P. and there is no evidence of faulting events between $\sim 3360$ (sample Oling C-1; Fig. 7, Table 1) and at least $\sim 7600$ cal. yr B.P. (Mazama tephra; Fig. 7). Two samples of detrital charcoal obtained from colluvium deposited in a depression along the scarp after the penultimate event (unit $\mathrm{C} 1$ ) show that the colluvium contains reworked material that is both older (sample Oling C-4; $4140 \pm 170$ cal. yr B.P.; Fig. 7, Table 1) and younger (sample Oling C-2; $2980 \pm 190$ cal. yr B.P.; Fig. 7, Table 1) than sample C-1 (Fig. 7). It is not known if the youngest charcoal incorporated in colluvial unit $\mathrm{C} 1$, sample Oling $\mathrm{C}-2$ (Fig. 7), was introduced into the colluvium after the penultimate earthquake or is reworked from unit 4; thus this date does not provide a clear bound on the recency of the penultimate earthquake or the maximum age of the penultimate earthquake. However, sample Oling C-2 does limit the most recent earthquake to after $2980 \pm 190 \mathrm{cal}$. yr B.P. No datable material was found in colluvial unit $\mathrm{C} 2$ or the vesicular silt cap unit Av, so the minimum age of the most recent earthquake cannot be determined. Because the only unfaulted deposits are unit $5 \mathrm{c}$ and the Av soil horizon, it is probably relatively young (Fig. 7).

\section{Trench 2}

Trench 2 (Figs. 3 and 8) was excavated across a small scarp $(0.4 \mathrm{~m})$ formed in an intermittent stream channel along the western section of the fault near Tracy. This location was chosen so that young deposits offset during the most recent earthquake could be investigated along the western end of the fault. Trench 2 exposed thick packages of poorly sorted 

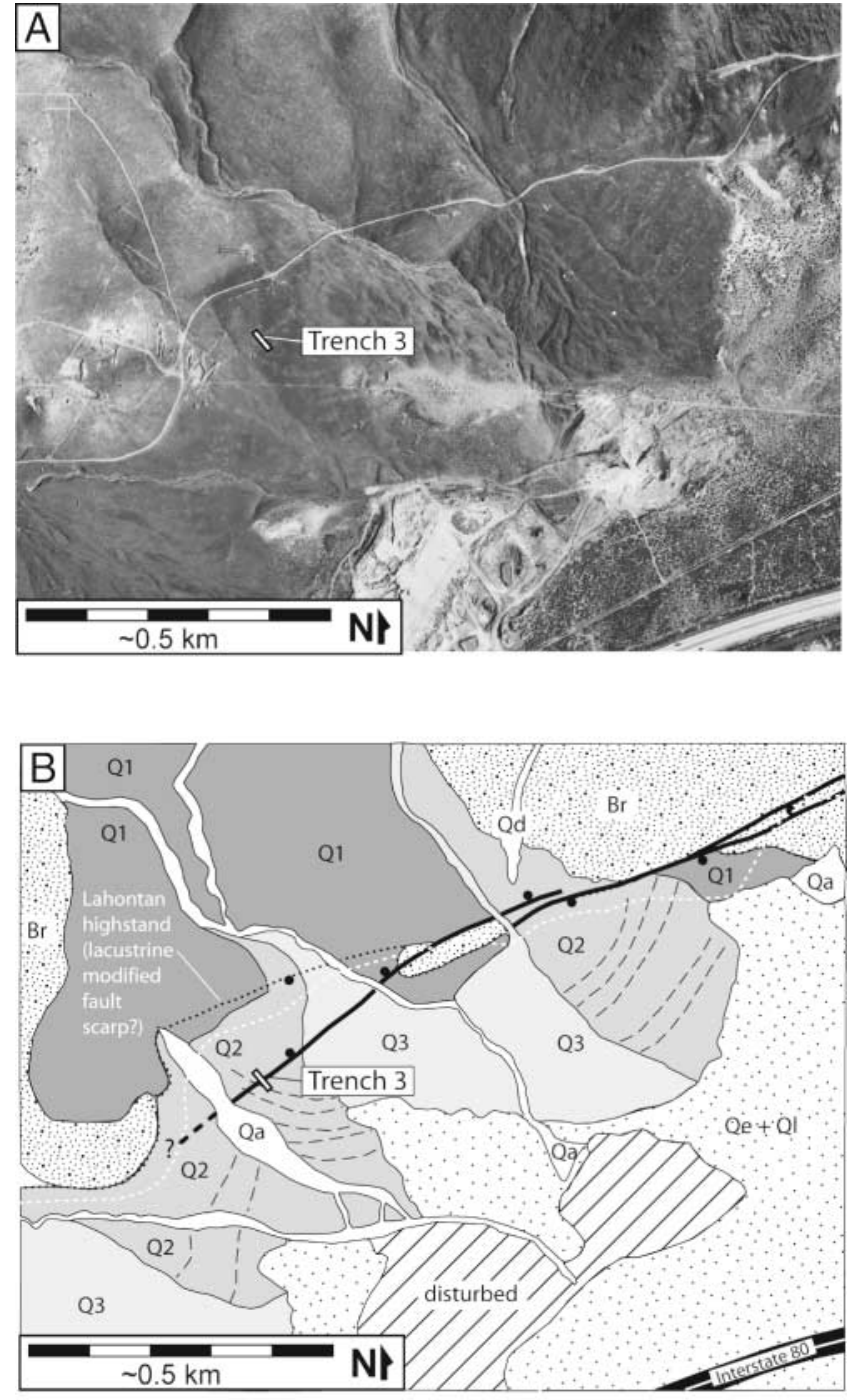

Figure 6. (A) Low-sun-angle vertical airphoto showing location of trench 3. See Figure 3 for location. (B) Map of airphoto area. Fault is heavy black line, ball on downdropped side. Qa, active alluvium; Q3-Q1, progressively older alluvium; Qe + Q1, undifferentiated eolian and lacustrine deposits; Qd, debris flow; $\mathrm{Br}$, bedrock; Lahontan highstand $(\sim 1337 \mathrm{~m})$ shown by dotted black line; Lahontan erosional shorelines shown by black dashed lines; white dotted line is road.

fluvial sands and gravels (units 1-3) and a small package of scarp-derived colluvium (unit C) (Fig. 9).

Trench 2 contains stratigraphic and structural evidence for a single earthquake (Fig. 9). The fault is marked by a broad (1-2 m) zone of disrupted bedding, with concentrated coarse clasts in the fault zone exhibiting a poorly developed vertical shear fabric. The fault extends nearly to the surface and is aligned with the surface scarp. Apparent vertical offsets across the fault range from $0 \mathrm{~cm}$ at the base of the exposure (top of unit 1) to $40 \mathrm{~cm}$ at the ground surface (unit 3 ). The apparent increase in vertical separation upward in the exposure reflects lateral offset of packages with nonhorizontal contacts, a relationship consistent with strike-slip faulting. A small colluvial wedge (unit C; Fig. 9) is derived from the surface scarp. Detrital charcoal was collected from unit 3 in trench 2 (sample Tracy-C1; Fig. 9, Table 1). The radiocarbon age of the detrital charcoal, $1935 \pm 70 \mathrm{cal}$. yr B.P., represents the maximum age of unit 3 and is thus the maximum age of the earthquake preserved in the trench 2 exposure.

\section{Trench 3}

Trench 3 (Figs. 3 and 6) was emplaced across a 0.15to $0.2-\mathrm{m}$ (vertical separation) uphill-facing scarp formed on an alluvial fan in the western section of the fault zone near Tracy (Fig. 2). Recessional shorelines preserved in the surface of the alluvial fan are faulted (Fig. 6), indicating that the scarp-forming earthquake postdates desiccation of Lake Lahontan $(\sim 15.5 \mathrm{ka})$. The location of trench 3 takes advantage of the clear relationship between Lake Lahontan shoreline features and surface faulting here; however, the proximity of the site to the end of the mapped fault trace raises the possibility that the trenched deposits do not fully record surface-rupturing earthquakes along this section of the fault. The deposits exposed in trench 3 (Fig. 10) are debris flow deposits with occasional interbedded channel gravels (units 1 and 3), fluvial gravels (unit 2), and colluvial packages (C1-C3).

Stratigraphic and structural evidence for three earthquakes is preserved in trench 3 (Fig. 10). Two well-defined fault strands (FN and FS, Fig. 10) displace and deform the exposed deposits and are identified on the basis of truncation and juxtaposition of dissimilar depositional units across the fault, clast alignment, and shear fabric, and the incorporation and deformation of alluvium and fissure fill within the fault zone. The oldest earthquake is associated with offset of units 1 and 2 by fault strand FS and subsequent deposition of scarp-derived colluvium $\mathrm{C} 1$ on unit 2 . The penultimate earthquake is recorded by faulting of colluvial package $\mathrm{C} 1$ and deposition of scarp-derived colluvium $\mathrm{C} 2$ on top of $\mathrm{C} 1$. The most recent earthquake is recorded by offset of $\mathrm{C} 2$ and unit 3 by fault strand FS and faulting of unit 3 and deposition of possible colluvial package C3 by fault FN. The most recent earthquake had less vertical offset than the previous two earthquakes, and in an opposite sense (north side down; Fig. 10); such variations are common on strike-slip faults. Fault strand FN juxtaposes dissimilar facies of unit 1 against one another, and unit 2 is entirely absent north of strand FN, implying significant horizontal displacement and possible stripping before deposition of debris flow unit 3 .

Age control for paleoearthquakes preserved in trench 3 is provided by radiocarbon ages obtained from the upper $5 \mathrm{~cm}$ of buried paleosols preserved on colluvial deposits $\mathrm{C} 1$ and C2 (Fig. 10). Apparent mean residence time (AMRT) radiocarbon ages of humic acids extracted from bulk samples approximate the maximum age of the paleosols at the 

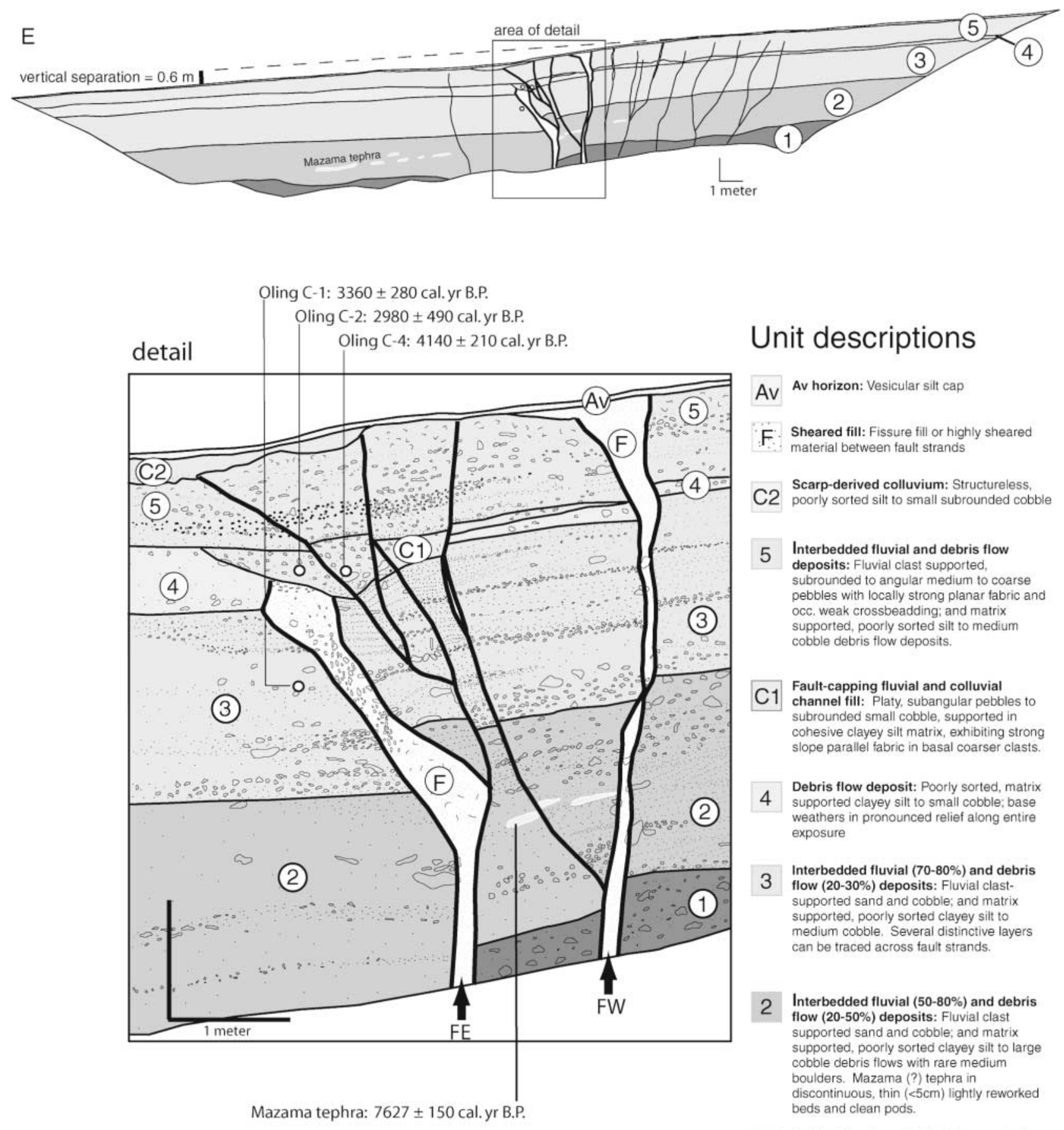

Unit descriptions

Av Av horizon: Vesicular silt cap

F. Sheared fill: Fissure fill or highly sheared material between fault strands

Scarp-derived colluvium: Structureless,

C2 poorly sorted silt to small subrounded cobble

5 Interbedded fluvial and debris flow deposits: Fluvial clast supported, subrounded to angular medium to coarse pebbles with locally strong planar fabric and occ. weak crossbeadding: and matrix supported, poorly sorted silt to medium cobble debris flow deposits.

-1 Fault-capping fluvial and colluvial channel fill: Platy, subangular pebbles to subrounded small cobble, supported in cohesive clayey silt matrix, exhibiting strong slope parallel fabric in basal coarser clasts.

4 Debris flow deposit: Poorly sorted, matrix supported clayey silt to small cobble; base weathers in pronounced relief along entire exposure

Interbedded fluvial $(70-80 \%)$ and debris flow $(20-30 \%)$ deposits: Fluvial clastflow $(20-30 \%)$ deposits: Fluvial clast-
supported sand and cobble; and matrix supported, poorly sorted clayey silt to medium cobble. Several distinctive layers can be traced across fault strands.

2 Interbedded fluvial (50-80\%) and debris flow $(20-50 \%)$ deposits: Fluvial clast supported sand and cobble; and matrix supported, poorly sorted clayey silt to large cobble debris flows with rare medium boulders. Mazama (?) tephra in discontinuous, thin $(<5 \mathrm{~cm})$ lightly reworked beds and clean pods

Debris flow deposit: Matrix supported, poorly sorted silt to angular large cobble, occ. clean lenses of mod. sorted. subangular coarse pebbles

Figure 7. Trench log, trench 1. See Figures 2, 3, and 4 for location.

time of burial (Matthews, 1980; Machette et al., 1992; Birkeland, 1999; Anderson et al., 2002). The dated soils formed on scarp-related colluvium and were buried after subsequent earthquakes, and therefore the AMRT radiocarbon soil ages provide broad constraints on earthquake timing. Sample Pat
Soil-1 from the top of colluvial package $\mathrm{C} 1$ yielded an AMRT radiocarbon age of 19,800 \pm 630 cal. yr B.P. and thus the earthquake that formed the scarp from which colluvial package $\mathrm{C} 1$ is derived (Fig. 10) took place before this time. Because colluvium $\mathrm{C} 1$ is buried directly by colluvial 
Table 1

Radiocarbon Data from Olinghouse Trenches

\begin{tabular}{|c|c|c|c|c|c|}
\hline Sample & Lab No. & ${ }^{14} \mathrm{C}$ age* $\pm 1 \sigma$ & $\delta^{13} \mathrm{C}^{\dagger}$ & $\begin{array}{l}\text { Calendar Years Before Present } \\
\text { (cal. yr B.P.; entire } 2 \sigma \text { range) }\end{array}$ & $\begin{array}{l}\text { Calendar Dates A.D./B.C. } \\
\text { (Entire } 2 \sigma \text { Range) }\end{array}$ \\
\hline Oling C-1 & $77318^{\S}$ & $3,170 \pm 90$ & -25 & $3,360 \pm 280$ & BC $1,070 \pm 530$ \\
\hline Oling C-2 & $81207^{\S}$ & $2,880 \pm 190$ & -25 & $2,980 \pm 490$ & BC $1,410 \pm 275$ \\
\hline Oling C-4 & $77318^{\S}$ & $3,760 \pm 60$ & -25 & $4,140 \pm 210$ & BC $2,190 \pm 210$ \\
\hline Tracy C-1 & $109426^{\S}$ & $1,990 \pm 35$ & -25 & $1,935 \pm 70$ & $6 \pm 30 \mathrm{AD}$ \\
\hline Pat-Soil 1 & $30503^{\mathbb{I I}}$ & $16,610 \pm 70$ & -23.1 & $19,800 \pm 630$ & BC $17,860 \pm 630$ \\
\hline Pat-Soil 2 & $30504^{\text {II }}$ & $10,880 \pm 50$ & -22.9 & $12,890 \pm 240$ & BC $10,940 \pm 240$ \\
\hline
\end{tabular}

*Using Libby half-life of 5568 years; relative to A.D. 1950.

${ }^{\dagger}$ Values are assumed according to Stuiver and Polach (1977) when given without decimal places.

*Dendrochronologically calibrated ages calibrated with Stuiver and Reimer (1993) (version 4.4) using Stuiver et al. (1998).

${ }^{8}$ Samples processed and AMS ${ }^{14} \mathrm{C}$ measurement performed at Center for Accelerator Mass Spectrometry (CAMS) at Lawrence Livermore National Laboratory.

"Samples processed by Geochron Laboratories.

package $\mathrm{C} 2$, we interpret the bulk soil date from colluvial package $\mathrm{C} 1(19,800 \pm 630 \mathrm{cal}$. yr B.P. $)$ as approximating the age of the penultimate earthquake. Bulk soil sample Pat Soil-2 is from the soil developed on colluvial package C2 and yields an AMRT radiocarbon age of 12,890 $\pm 240 \mathrm{cal}$. yr B.P. This age is inconsistent with $\sim 15.5$ ka Lake Lahontan erosional shoreline features formed on the trenched deposits (Fig. 10) The artificially young age may be due to growth and decay of young roots in the buried soil. The most recent earthquake offset colluvium $\mathrm{C} 2$ and the uppermost deposit unit 3, indicating that the most recent earthquake took place after $\sim 15.5$ cal. yr B.P., the age of the Lake Lahontan highstand.

\section{Discussion}

Trench exposures along the Olinghouse fault zone record different Holocene and latest Pleistocene earthquake histories (Figs. 7, 9, and 10). Near the eastern end of the fault, trench 1 exposes evidence for two or three surface-rupturing earthquakes after $3360 \pm 190 \mathrm{cal}$. yr B.P., with the most recent earthquake occurring sometime after $2980 \pm 190 \mathrm{cal}$. yr B.P. (Fig. 7). There is no evidence in trench 1 for paleoearthquakes between $\sim 3360$ and 7600 cal. yr B.P., and soil relationships suggest that the most recent earthquake may be relatively young. At the western end of the fault in trench 3, the oldest recorded event occurred some unknown time before 19,800 $\pm 630 \mathrm{cal}$. yr B.P., the penultimate event occurred between 19,800 $\pm 630 \mathrm{cal}$. yr B.P. and $\sim 15.5 \mathrm{cal}$. yr B.P., and the most recent earthquake occurred sometime after $\sim 15.5$ cal. yr B.P. (Fig. 10). Trench 2 (Fig. 9) further limits the recency of the most recent earthquake on the western section of the fault to after $1935 \pm 70$ cal. yr B.P.

An event timeline (Fig. 11) highlights the differences in earthquake timing between the eastern and western ends of the fault. Recent earthquakes appear to have occurred more frequently at the eastern end of the fault (trench 1; Fig. 7) than at the western end (trenches 2 and 3; Figs. 9 and 10). The more frequent occurrence of recent earthquakes occurs near where the Olinghouse fault zone intersects the Pyramid Lake fault zone (Fig. 2), leading us to suggest that the cluster of recent earthquakes at the eastern end of the Olinghouse fault zone reflects interaction with the conjugate Pyramid Lake fault. The northwest-striking, right-lateral strike-slip Pyramid Lake fault zone has been the location of at least four earthquakes since $\sim 15.5 \mathrm{ka}$ (Anderson and Hawkins, 1984; Briggs and Wesnousky, 2004) (Fig. 9). Triggered slip on conjugate strike-slip faults has been documented for several historical North American interior earthquakes, including the 1987 Superstition Hills/Elmore Ranch (Magistrale et al., 1989; Hudnut et al., 1989; Sharp et al, 1989), the 1994 Double Springs Flat (Ichinose et al., 1998; Amelung and Bell, 2003), and the 1986 Chalfant Valley (Cockerham and Corbett, 1987; Smith and Priestly, 2000) events. Although the resolution of our paleoseismic data do not allow positive identification of a triggered earthquake, comparison of the composite paleoseismic record for the Pyramid Lake fault zone (Briggs and Wesnousky, 2004) with the record obtained here for trenches 1-3 shows that one or more recent earthquake ruptures may have occurred close in time on both faults (Fig. 9). The possibility of triggered slip on the Olinghouse fault caused by earthquakes on neighboring faults was suggested by Cashman and Ellis (1994) as a possible cause for multiple slickenside orientations on a bedrock exposure at the west end of the Olinghouse fault.

Late Pleistocene and Holocene paleoearthquake recurrence appears to have been irregular on the Olinghouse fault zone (Fig. 11). Data from trench 1 near the eastern end of the fault (Fig. 7) indicate that the interval between the penultimate and most recent earthquakes was between $\sim 380$ and $\sim 3400$ years (Fig. 11). These values are much shorter than previous estimates for the Olinghouse fault zone. Sanders and Slemmons (1996) estimated two or three large earthquakes in the last $21 \mathrm{ka}$ along the eastern portion of the Olinghouse fault zone on the basis of scarp degradation 

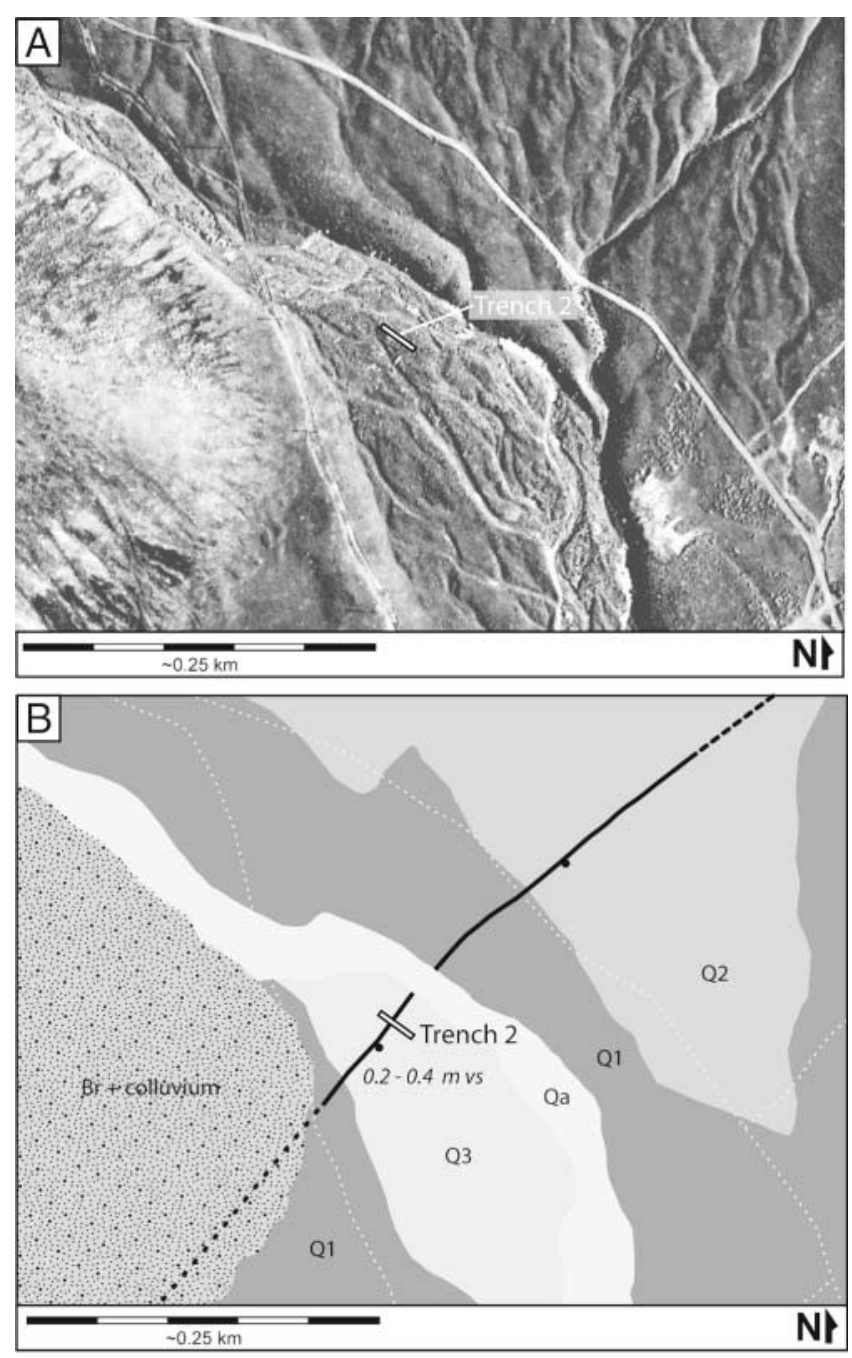

Figure 8. (A) Low-sun-angle vertical airphoto showing location of trench 2. See Figure 3 for location. (B) Map of airphoto area. Fault is heavy black line, ball on downdropped side; dashed where lineament and dotted where concealed. Qa, active alluvium, Q3-Q1, progressively older alluvium; Br, bedrock; white dotted line is road.

modeling and inferred an earthquake recurrence interval of 8 to $16 \mathrm{ka}$. When the records from trenches 2 and 3 at the western end of the fault are considered together, the interval between the penultimate and most recent earthquakes is between $\sim 13,600$ and $\sim 17,900$ years. This is an interval much longer than that observed in at the eastern end (Figs. 7 and 10) and thus we cannot assign a single average earthquake recurrence interval to the fault zone.

Fault trace map patterns and fault scarp morphology provide indirect evidence of differential behavior and possible fault segmentation between the eastern and western ends of the Olinghouse fault zone, in agreement with trench observations. In general, fault scarps formed in alluvium at the eastern end of the fault zone are more continuous and better preserved than those at the western end (Fig. 3) (Sand- ers and Slemmons, 1996). The central portion of the active fault is discontinuous and cuts across topography along a broad zone in bedrock of the Pah Rah Range, and this central portion may represent a segment boundary for ruptures occurring on the eastern portion of the fault (Fig. 3).

The Olinghouse fault zone is hypothesized to have been the source of a large historical earthquake (Slemmons, 1977; Sanders and Slemmons, 1979; Toppozada et al., 1981; Sanders and Slemmons, 1996; dePolo et al., 1997). Earthquakes that occurred in western Nevada in 1860 (M 6.3-7.0) and 1869 ( $M$ 6.1-6.7) have been linked to the Olinghouse fault on the basis of an eyewitness account of surface cracks that formed sometime in the 1860s (Slemmons, 1977). However, isoseismal maps do not place the 1860 and 1869 earthquakes on the Olinghouse fault, but instead locate the 1860 event near Pyramid Lake and the 1869 event south of Reno (Fig. 2) (Toppozada et al., 1981). Sanders and Slemmons (1996) inferred an age of $4.5 \pm 2.0 \mathrm{ka}$ for the most recent earthquake on the Olinghouse fault, on the basis of scarp profile modeling, and suggested that if a historical earthquake did indeed occur on the fault, it may have produced purely lateral offsets. Our observations indicate that a minimum of $30 \mathrm{~cm}$ of normal displacement accompanied the most recent event (Fig. 7), and the possibility that a historical event was overlooked because it produced purely lateral slip is unlikely. Our trench data show that the western portion of the fault was the source of a strike-slip earthquake sometime after $2980 \pm 190$ cal. yr B.P., and although our exposures do not allow determination of a minimum age for the most recent earthquake, qualitative observations suggest that the Olinghouse fault may not have been the source of a historical earthquake. Relatively few locations along the fault trace preserve unambiguous lateral offsets of young deposits (Fig. 3), an observation at odds with the occurrence of a $<150$-year-old strike-slip earthquake in this arid region. The combined weight of isoseismal data (Toppozada et al., 1981), significant coseismic vertical and lateral deformation (Fig. 7), and present-day subdued fault zone geomorphology suggests to us that the Olinghouse fault zone may not have been the source of the 1860 or 1869 earthquake.

Several factors combine to make the Olinghouse fault zone a potential source of seismic hazard for the RenoSparks metropolitan area (population $>350,000$ ) (Fig. 2). The fault lies within $15 \mathrm{~km}$ of Reno and, more importantly, strikes directly toward it (Fig. 2). The orientation and lateral sense of slip on the fault (Fig. 4) may cause large earthquakes to direct energy (Somerville et al., 1997) toward the basin beneath Reno. Our observations bearing on earthquake recency suggest that the fault may not have experienced a historic earthquake, and, if this is the case, the fault may not be at the beginning of the strain accumulation and release cycle. Our paleoseismic and mapping data suggest that the fault has ruptured more often recently at the eastern end than at the western end, suggesting that the Olinghouse fault zone may experience triggered slip at its eastern end because of earthquakes on the conjugate Pyramid Lake fault (Fig. 9) 


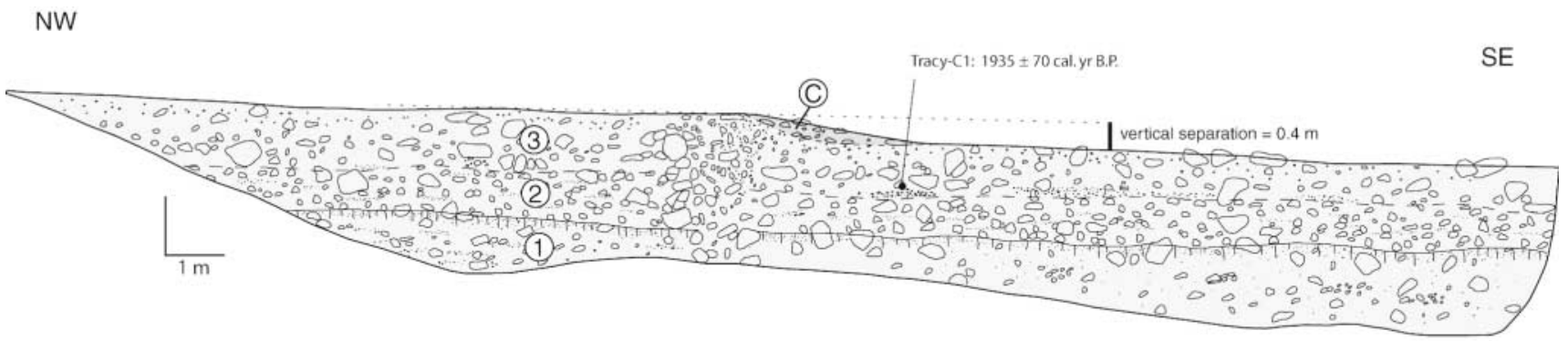

Units
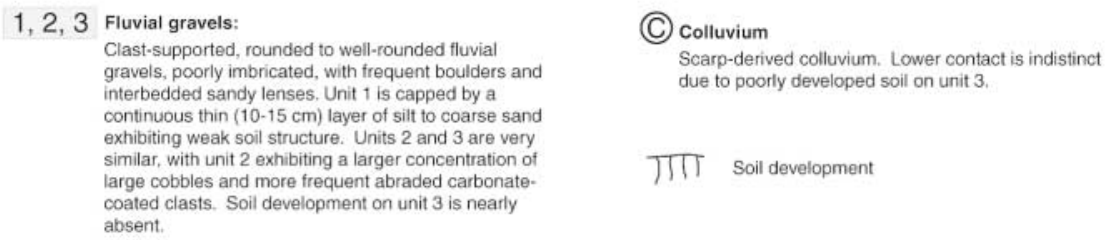

Figure 9. Trench log, trench 2. See Figures 2, 3, and 8 for location.

$\mathrm{N}$

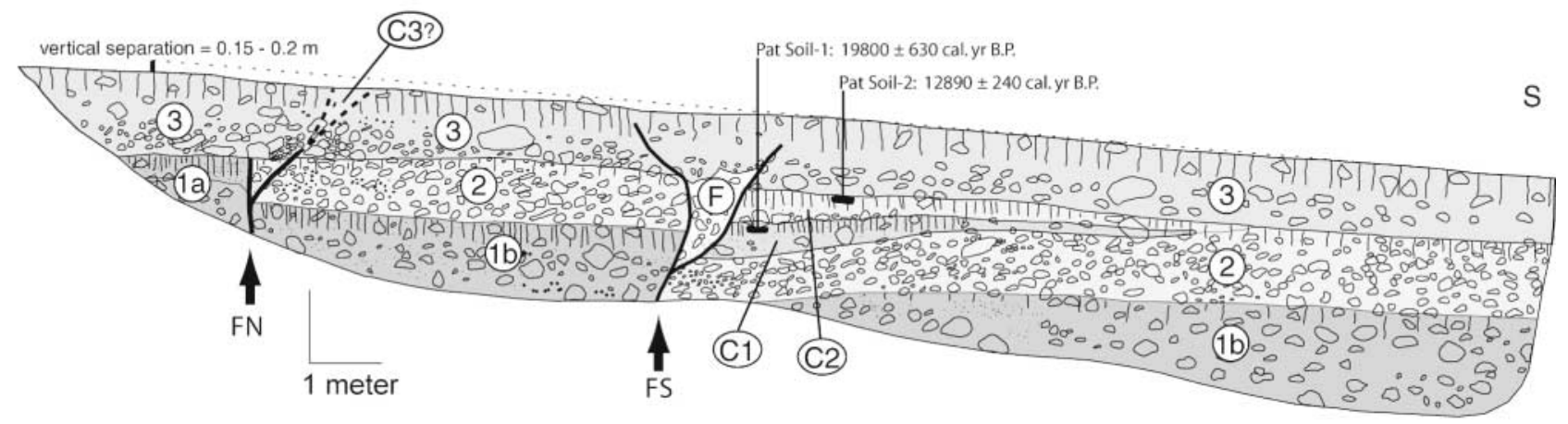

Units

1a,b Debris flow deposit:

Poorly sorted silt to small boulders, largely clast supported, clasts subangular to rounded, matrix loose siltfine sand. Unit 1a is capped by coarse sand north of fault strand $\mathrm{FN}$; cap is absent on $1 \mathrm{~b}$.

2 Fluvial gravels:

Mod. sorted, clast supported pebble to large cobble, coarse sand matrix, Clasts abraded (varnish scoured off) and flattened, many imbricated and dipping north.

(C1) Colluvial package 1:

Poorly sorted, fining-upward large cobble to silt; weak soil development
(C2) Colluvial package 2:

Similar to $\mathrm{C} 1$, but with more pronounced sorting between basal large clasts and upper sands and silts. Sharp continuous contact with $\mathrm{C} 1$. Weak soil development

TIT Soil development

(F) Sheared fill

3 Debris flow deposit:

Poorly sorted coarse sand to medium boulders, mostly rounded, no obvious imbrication direction. Largely clast supported. Degree of clast rounding seems to reflect remobilization of lacustrine clasts from upslope.

C3? Colluvial package (?) 3:

Concentration of finer-grained material and disruption of soil horizonation associated with projection of fault strands from below.

Figure 10. Trench $\log$, trench 3. See Figures 2, 3, and 6 for location.

and, conversely, may rupture in less frequent, but possibly larger, earthquakes along the western portion. In addition to treating the Olinghouse fault zone as an independent source, seismic hazard models might include the possibility that the Pyramid Lake and Olinghouse faults may rupture together or in quick succession, and that triggered slip on the Olinghouse may rupture the entire length of the fault. Historical data suggest that strike-slip earthquakes with rupture lengths of $\sim 25 \mathrm{~km}$ are typically of magnitude 6.5-6.9 (Wells and Coppersmith, 1994). 


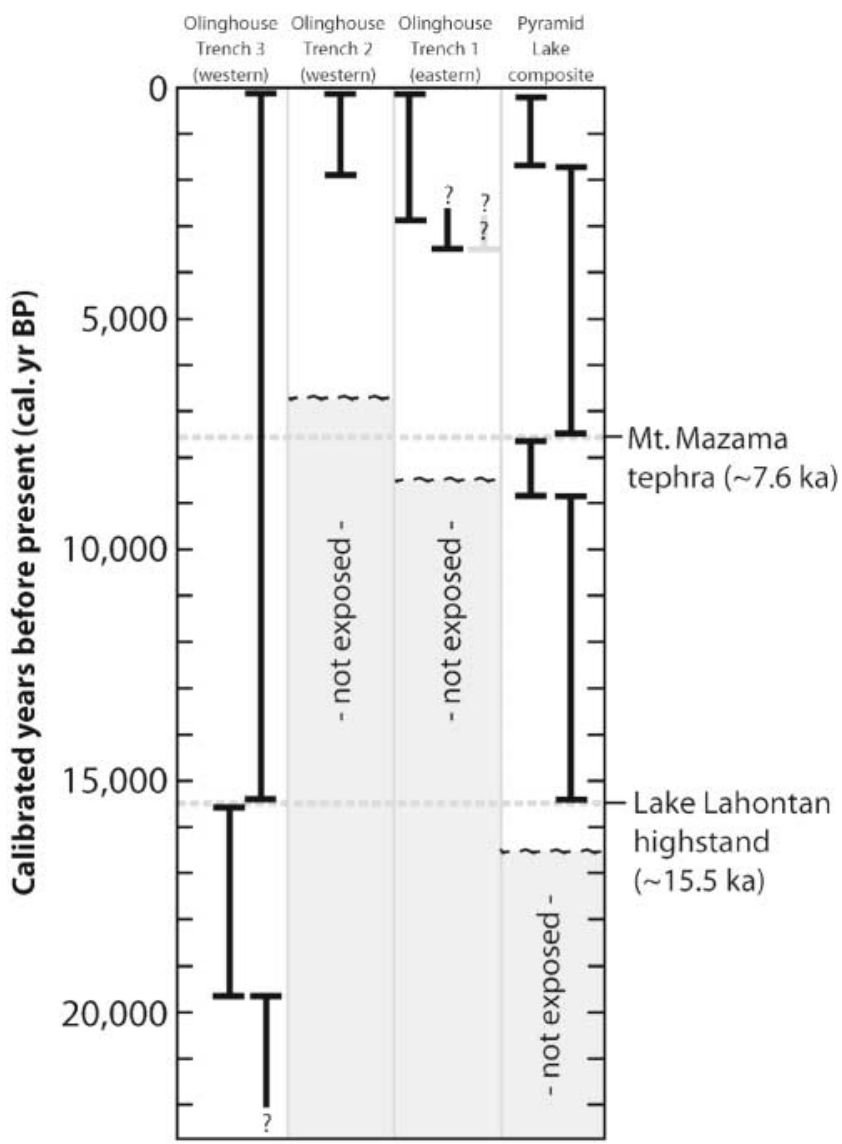

Figure 11. Summary of paleoearthquake timing of Olinghouse and Pyramid Lake fault zone trench exposures. Dark bars represent time interval during which each earthquake may have occurred. Grey line in Trench 1 is possible 3rd earthquake. Pyramid Lake fault zone composite record from Briggs and Wesnousky (2004).

\section{Conclusions}

We combine fault trace mapping and paleoseismic trench observations to clarify the recent earthquake history of the Olinghouse fault. The fault exhibits a variable earthquake history along strike. At the eastern end, the fault has been the source of two and possibly three surface-rupturing earthquakes since $3360 \pm 190$ cal. yr B.P., with the penultimate earthquake occurring after $3360 \pm 190$ cal. yr B.P. and the most recent earthquake after $2980 \pm 190 \mathrm{cal}$. yr B.P. The western end of the Olinghouse fault zone has been the source of three latest Pleistocene and Holocene earthquakes, with the oldest event occurring before 19,800 $\pm 630 \mathrm{cal}$. yr B.P., the penultimate event between 19,800 \pm 630 and $\sim 15,500$ cal. yr B.P., and the most recent earthquake after $1935 \pm 70$ cal. yr B.P. Our excavations do not place a limit on the recency of the most recent earthquake, but fault geomorphology suggests that the Olinghouse fault zone may not be the source of a historical ground-rupturing earthquake, a conclusion supported by previous isoseismal studies (Toppozada et al., 1981). The higher frequency of recent earthquakes at the eastern end of the fault may reflect interaction with the conjugate Pyramid Lake fault zone. Our observations document Holocene earthquake activity on the Olinghouse fault zone and suggest interaction with the Pyramid Lake fault zone, and thus demonstrate that northeasttrending left-lateral faults such as the Olinghouse fault actively accommodate northwest-directed right-lateral shear of the northern Walker Lane.

\section{Acknowledgments}

This study was funded in part by the National Earthquake Hazards Reduction Program Project 02HQGR0037. D. Burt Slemmons cheerfully reviewed our field observations and frequent discussions with him helped focus this project. Christopher Sanders generously provided a set of airphotos. Andrew Rael provided important field observations early in the project. Thoughtful reviews by Phil Pearthree, Alessandro Michetti, Associate Editor Daniela Pantosti, and especially Steve Personius greatly improved this article. Finally, Wade Pearson gave us access to his mine lease and used his own excavator to dig Trench 1; we are deeply saddened by his passing and dedicate this small effort to him. Center for Neotectonic Studies contribution no. 47.

\section{References}

Adams, K. D., and S. G. Wesnousky (1999). The Lake Lahontan highstand: age, surficial characteristics, soil development, and regional shoreline correlation, Geomorphology 30, no. 4, 357-392.

Amelung, F., and J. W. Bell (2003). Interferometric synthetic aperture radar observations of the 1994 Double Spring Flat, Nevada, earthquake (M5.9): main shock accompanied by triggered slip on a conjugate fault, J. Geophys. Res 108, no. B9, 2433, doi 10.1029/2002JB001953.

Anderson, K., S. Wells, and R. Graham (2002) Pedogenesis of vesicular horizons, Cima volcanic field, Mojave Desert, California, Soil Sci. Soc. Am. J. 66, 878-887.

Anderson, L., and F. F. Hawkins (1984). Recurrent Holocene strike-slip faulting, Pyramid Lake fault zone, western Nevada, Geology 12, 681684.

Bennett, R. A., B. P. Wernicke, N. A. Niemi, A. M. Friedrich, and J. L. Davis (2003). Contemporary strain rates in the northern Basin and Range province from GPS data, Tectonics 22, no. 2, 1008, doi 10.1029/200ITC001355.

Birkeland, P. W. (1999). Soils and Geomorphology, Third Ed., Oxford University Press, New York, 430 pp.

Bonham, H. F. (1969). Geology and mineral deposits of Washoe and Storey Counties, Nevada, Nevada Bureau of Mines and Geology, Bulletin 70, pp. 140.

Bonham, H. F., Jr., and J. W. Bell (1993). Geologic map of the Steamboat 71/2-minute Quadrangle, Nevada Bureau of Mines and Geology Map $4 \mathrm{Fg}$.

Briggs, R. W., and S. G. Wesnousky (2004). Late Pleistocene fault slip rate, earthquake recurrence, and recency of slip along the Pyramid Lake fault zone, northern Walker Lane, United States, J. Geophys. Res. 109, no. B8, B08402, doi 10.1029/2003JB002717.

Cashman, P. H., and M. A. Ellis (1994). Fault interaction may generate multiple slip vectors on a single fault surface, Geology 22, 11231126.

Cockerham, R. S., and E. J. Corbett (1987). The 1986 Chalfant valley, California, earthquake sequence: preliminary results, Bull. Seism. Soc. Am. 77, no. 1, 280-289.

dePolo, C. M., J. G. Anderson, D. M. dePolo, and J. G. Price (1997). Earthquake Occurrence in the Reno-Carson City Urban Corridor, Seism. Res. Lett. 68, no. 3, 401-412. 
Dixon, T. H, M. Miller, F. Farina, H. Wang, and D. Johnson (2000). Present-day motion of the Sierra Nevada block and some tectonic implications for the Basin and Range province, North American Cordillera, Tectonics 19, no. 1, 1-24.

Dohrenwend, J. C., B. A. Schell, C. M. Menges, B. C. Moring, and M. A. McKittrick (1996). Reconnaissance photogeologic map of young (Quaternary and late Tertiary) faults in Nevada, in Analysis of $\mathrm{Ne}$ vada's Metal-Bearing Mineral Resources, D. A. Singer (Editor), Nevada Bureau of Mines and Geology Open-File Report 96-2, 1 pl., scale $1: 1,000,000$.

Dokka, R. K., and C. J. Travis (1990). Role of the eastern California shear zone in accommodating Pacific-North American plate motion, Geophys. Res. Lett. 17, no. 9, 1323-1326.

Garside, L. J., S. B. Castor, C. H. Henry, and J. E. Faulds (Editors) (2000). Structure, volcanic stratigraphy, and ore deposits of the Pah Rah Range, Washoe County, Nevada, in Geological Society of Nevada Symposium 2000 Field Trip Guidebook No. 2, pp. 132.

Greene, R. C., J. H. Stewart, D. A. John, R. F. Hardyman, N. J. Silberling, and M. L. Sorensen (1991). Geologic map of the Reno $1^{\circ}$ by $2^{\circ}$ quadrangle, Nevada and California, U.S. Geological Survey Miscellaneous Field Studies Map MF-2154-A, scale 1:250,000.

Hammond, W. C., and W. Thatcher (2004). Contemporary tectonic deformation of the Basin and Range province, western United States: 10 years of observation with the Global Positioning System, J. Geophys. Res. 109, B08403, doi 10.1029/2003JB002746.

Hudnut, K. W., L. Seeber, and T. Rockwell (1989). Slip on the Elmore Fault during the Past 330 Years and its Relation to Slip on the Superstition Hills Fault, Bull. Seism. Soc. Am. 79, no. 2, 330-341.

Ichinose, G. A., K. D. Smith, and J. G. Anderson (1998). Moment tensor solutions of the 1994 to 1996 Double Spring Flat, Nevada, earthquake sequence and implications for local tectonic models, Bull. Seism. Soc. Am. 88, no. 6, 1363-1378.

Machette, M. N., S. F. Personius, and A. R. Nelson (1992). Paleoseismology of the Wasatch fault zone: a summary of recent investigations, interpretations, and conclusions, in Assessment of regional Earthquake Hazards and Risk Along the Wasatch Front, Utah, P. L. Gori and W. W. Hays (Editors), U.S. Geol. Surv. Profess. Pap. 1500-A, $71 \mathrm{p}$.

Magistrale, H., L. Jones, and H. Kanamori (1989). The Superstition Hills, California, Earthquakes of 24 November 1987, Bull. Seism. Soc. Am. 79, no. 2, 239-251.

Matthews, J. A. (1980) Some problems and implication of ${ }^{14} \mathrm{C}$ dates from a podzol buried beneath an end moraine at Haugabreen, southern Norway, Geografis. Ann. 62A, 185-208.

Minster, J. B., and T. H. Jordan (1987). Vector constraints on Western U.S. deformation from space geodesy, neotectonics, and plate motions, $J$. Geophys. Res. B, Solid Earth Planets 92, no. 6, 4798-4804.

Pezzopane, S. K., and R. J. Weldon (1993). Tectonic role of active faulting in central Oregon, Tectonics 12, 1140-1169.

Robyn, T. L. (1994). Geology and ore controls of the Lower Olinghouse Placer Gold Mine, Nevada, Econ. Geol. 89, 1614-1622.

Sanders, C. O., and D. B. Slemmons (1979). Recent crustal movements in the Central Sierra Nevada-Walker Lane region of California-Nevada. Part III: The Olinghouse fault zone, Tectonophysics 52, 585-597.

Sanders, C. O., and D. B. Slemmons (1996). Geomorphic evidence for Holocene Earthquakes in the Olinghouse Fault Zone, Western Nevada, Bull. Seism. Soc. Am. 86, no. 6, 1784-1792.

Savage, J. C., M. Lisowski, and W. H. Prescott (1990). An apparent shear zone trending north-northwest across the Mojave Desert into Owens Valley, eastern California, Geophys. Res. Lett. 17, no. 12, 2113-2116.

Sharp, R. V., K. E. Budding, J. Boatwright, M. J. Ader, M. G. Bonilla, M. M. Clark, T. E. Fumal, K. K. Harms, J. J. Lienkaemper, D. M. Morton, B. J. O'Neil, C. L. Ostergren, D. J. Ponti, M. J. Rymer, J. L. Saxton, and J. D. Sims (1989). Surface faulting along the Superstition Hills Fault Zone and nearby faults associated with the earthquakes of 24 November 1987, Bull. Seism. Soc. Am. 79, no. 2, 252-281.
Slemmons, D. B. (1977). State-of-the-art for assessing earthquake hazards in the United States: Report 6, faults and earthquake magnitude, U.S. Army Engineer Waterways Experiment Station Miscellaneous Paper S-73-1, 129 p. with 37 p. appendix.

Smith, K. D., and K. F. Priestley (2000). Faulting in the 1986 Chalfant, California, sequence: Local tectonics and earthquake source parameters, Bull. Seism. Soc. Am. 90, no. 4, 813-831.

Somerville, P. G., N. F. Smith, R. W. Graves, and N. A. Abrahamson (1997). Modification of empirical strong ground motion attenuation relations to include the amplitude and duration effects of rupture directivity, Seism. Res. Lett. 68, 199-222.

Stewart, J. H. (1988). Tectonics of the Walker Lane Belt, western Great Basin; Mesozoic and Cenozoic deformation in a zone of shear; in Metamorphism and Crustal Evolution of the Western United States, Rubey Volume, Vol. 7, Prentice-Hall, Englewood Cliffs, New Jersey, 683-713.

Stewart, J. H., and J. E. Carlson (1978). Geologic map of Nevada, U.S. Geological Survey, 1:500,000 scale.

Stuiver, M., and P. J. Reimer (1993). Extended C-14 database and revised CALIB 3.0 C-14 age calibration program, Radiocarbon 35, no. 1 , 215-230.

Stuiver, M., and H. A. Polach (1977). Discussion: Reporting of 14C data, Radiocarbon 19, no. 3, 355-363.

Stuiver, M., P. J. Reimer, E. Bard, J. W. Beck, G. S. Burr, K. A. Hughen, B. Kromer, F. G. McCormac, J. v. d. Plicht, and M. Spurk (1998). INTCAL98 Radiocarbon age calibration 24,000-0 cal BP, Radiocarbon 40, 1041-1083.

Svarc, J. L., J. C. Savage, W. H. Prescott, and A. R. Ramelli (2002). Strain accumulation and rotation in western Nevada, 1993-2000, J. Geophys. Res. B Solid Earth Planets 107, no. 5, 2090, doi 10.1029/ 2001JB000579.

Thatcher, W., G. R. Foulger, B. R. Julian, J. Svarc, E. Quilty, and G. W. Bawden (1999). Present-day deformation across the Basin and Range province, western United States, Science 283, 1714-1718.

Toppozada, T. R., C. R. Real, and D. L. Parke (1981). Preparation of isoseismal maps and summaries of reported effects for pre-1900 California earthquakes, Cal. Div. of Mines and Geol. Open-File Report 81-11, 182 pp.

U.S. Geological Survey (2003). Quaternary fault and fold database of the United States, ver. 1.0. U.S. Geol. Surv. Open-File Rept. 03-417, http://qfaults.cr.usgs.gov (last accessed November 2003).

Ward, S. N. (1990). Pacific-North America plate motions: new results from very long baseline interferometry, J. Geophys. Res. 95, no. B13, 21,965-21,981.

Wells, D. L., and K. J. Coppersmith (1994). New empirical relationships among magnitude, rupture length, rupture width, rupture area, and surface displacement, Bull. Seism. Soc. Am. 84, no. 4, 974-1002.

Yount, J. C., J. W. Bell, C. M. dePolo, A. R. Ramelli, P. H. Cashman, and P. A. Glancy (1993). Neotectonics of the Walker Lane, Pyramid Lake to Tonopah, Nevada. Part II: Road log, in Crustal evolution of the Great Basin and the Sierra Nevada, M. M. Lahren, J. H. Trexler, Jr., and C. Spinosa (Editors), Reno, Mackay School of Mines, University of Nevada, Geological Society of America, Cordilleran/Rocky Mountain section meeting, Reno, Nevada, 19-21 May 1993, Guidebook, 391-408.

Zdanowicz, C. M., G. A. Zielinski, and M. S. Germani (1999). Mount Mazama eruption: Calendrical age confirmed and atmospheric impact assessed, Geology 27, no. 7, 621-624.

Division of Geological and Planetary Sciences

California Institute of Technology

Pasadena, California 91125

briggs@gps.caltech.edu

Manuscript received 1 July 2004. 